(Uniwersytet Warmińsko-Mazurski, Olsztyn,

e-mail: akiklewicz@gmail.com)

ORCID: 0000-0002-6140-6368

\title{
OD ZNACZENIA DO KONCEPTU: PRAGMATYCZNO-KULTUROWE ASPEKTY SPECYFIKACJI SEMANTYCZNEJ
}

\begin{abstract}
WSTĘP
Przedmiotem niniejszego artykułu jest specyfikacja semantyczna jako stopień rozbudowania pojęcia leksykalnego w zależności od warunków funkcjonowania jednostek leksykalnych [więcej o tym pojęciu zob. Kiklewicz 2017a]. W ostatnich dziesięcioleciach odniosły sukces teorie lingwistyczne, głoszace, że tradycyjne opisy języka, zwłaszcza oparte na teorii i metodologii strukturalizmu, nie odzwierciedlaja naturalnego powiązania semantyki językowej z procesami zachodzącymi w umyśle. Nominację leksykalna postawiono niejako w opozycji do konceptualizacji, a znaczenie leksykalne (traktowane jako "systemowe”) - w opozycji do konceptu (jako „znaczenia kognitywnego”). Refleksje nad materiałem językowym nie potwierdzaja tych tez, dlatego celem artykułu będzie pokazanie, że kategorie „starej” lingwistyki, zwłaszcza kategoria znaczenia, także sa istotne $\mathrm{w}$ opisie zachodzacych $\mathrm{w}$ umyśle procesów przetwarzania informacji.
\end{abstract}

\section{W KIERUNKU SEMANTYKI FUNKCJONALNEJ}

W drugiej połowie XX wieku rozpowszechniły się koncepcje semantyki lingwistycznej, nawiazujace do antropologizmu - jako alternatywa dla strukturalizmu, a w szczególności dla teorii składników semantycznych [więcej o tym zob. Awdiejew 1999, 38 i n.], której genezy należy doszukiwać się w Kursie... F. de Saussure'a - w jego koncepcji „valeur”. W świetle strukturalizmu znaczenie jednostki jest zależne od jej miejsca w systemie języka i sprowadza się do zespołu cech dystynktywnych (czyli składników semantycznych), podczas gdy różne wersje - w terminologii

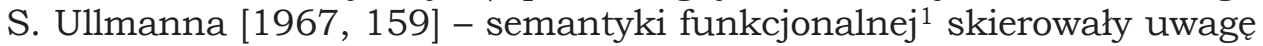

1 Ten kierunek badań jest także określany jako semantyka interpretacyjna [zob. Demiankow 1994, 21]. 
na czynnik egzekucyjny - osobę mówiąca, tzn. jej doświadczenia, wiedzę, nastawienia mentalne (znajdujace wyraz m.in. w procesach nominacji), intencje. Taki kierunek badań został obrany przede wszystkim przez badaczy identyfikujacych się z pragmatyzmem funkcjonalnym. Do tego nurtu nawiązuje np. zaproponowana przez A. Awdiejewa [2004, 15] koncepcja „sensów naddanych”. Funkcjonalizm w badaniach lingwistycznych drugiej połowy XX w. i poczatku XXI w. jest reprezentowany przez takie kierunki jak semantyka modalna i intensjonalna, teoria referencji, etnosemantyka (jako subdyscyplina w obrębie etnolingwistyki i lingwistyki kulturowej) oraz semantyka kognitywna. Szczególnym obiektem takich analiz stały się znaki indeksowe (określane także jako egocentryczne, według R. Jakobsona - „szyftery”).

Idee semantyki funkcjonalnej (zwłaszcza idioetnicznej) wywodzą się z XIX-wiecznego psychologizmu. Wówczas wybitny językoznawca, czołowy przedstawiciel Charkowskiej Szkoły Lingwistycznej A.A. Potiebnia [1993, 124 i n.], zaproponował rozróżnienie dwóch typów znaczeń: bliższego i dalszego. Pisał, że „znaczenie bliższe” ma charakter ogólnonarodowy, skonwencjonalizowany i względnie stabilny, podczas gdy „znaczenie dalsze” (zawierające różnego rodzaju konotacje i implikacje) ma charakter fakultatywny i wariantywny (w tym osobisty).

Rewolucja kognitywna drugiej połowy XX wieku polegała przede wszystkim na przyjęciu tezy o jednomodułowości umysłu, czyli tezy o przetwarzaniu informacji jezzykowej w procesach mentalnej konceptualizacji doświadczeń. W zwiazku z tym E. Tabakowska [2001, 30] pisze o przewadze kognitywnej teorii języka nad strukturalizmem: „O języku nie myśli się już w kategoriach umownego systemu znaków”, lecz w sposób bardziej reprezentacyjny i autentyczny („realistyczny”, jeśli posłużyć się określeniem Z. Muszyńskiego [zob. 1996, 34]), tj. przy uwzględnieniu ich motywacji. Skutkuje to antropocentrycznym (w pewnym sensie holistycznym) ujęciem znaczenia (czy też pojęcia) leksykalnego:

Jednostki języka nie sa niczym innym jak wynikiem subiektywnego spojrzenia człowieka na otaczający go świat. Znaczenie zaś jest równoznaczne z konceptualizacja, czyli z doświadczeniem umysłowym, tworzeniem subiektywnej struktury pojęciowej odpowiadającej naszemu widzeniu świata [Tabakowska 1995, 55].

Zakładając, że analiza znaczenia jest analizą struktur kognitywnych, językoznawcy kognitywni jako całkowicie arbitralny przyjmuja podział na semantykę i pragmatykę, i co za tym idzie - na informację słownikową i encyklopedyczną. Cała semantyka jest encyklopedyczna (...) [Kardela 1999, 17].

Semantyka kognitywna dąży do przedstawienia zintegrowanych z umysłem mechanizmów działalności językowej „zwykłych” użytkowników języka w warunkach codziennej komunikacji [zob. Gibbs, Matlock 2001, 217]. Podobnie lingwistyka kulturowa wychodzi z założenia, że opis pojęć leksykalnych powinien zostać dostosowany do rzeczywistych 
doświadczeń „normalnych użytkowników języka” - według określenia J. Bartmińskiego [1999, 113]. ${ }^{2}$ Właśnie do tych doświadczeń nie przystaja nadmiernie abstrakcyjne, naukowe definicje znaczeń w słownikach tradycyjnych, jak np. definicja stołówki: „zakład żywienia zbiorowego, dziś zwykle przy instytucji skupiajaccej wiele osób; także: sala jadalna takiego zakładu". ${ }^{3}$ Dlatego J. Bartmiński kwalifikuje takie definicje jako „systemowe” i uważa, że należy je odrzucić na rzecz definicji o charakterze „kognitywnym”, czyli naturalnym, autentycznym z punktu widzenia potrzeb w codziennej komunikacji.

\section{POJĘCIE KONCEPTU}

Takie holistyczne ujęcie znaczenia znalazło wyraz w pojęciu ko nc e ptu jako jednostki reprezentacji semantyki językowej w obrębie tzw. lingwokultury, czyli językowego obrazu świata, zintegrowanego z obrazem kulturowym. ${ }^{4}$ Opis konceptów (jako alternatywa dla opisu „znaczeń systemowych”) szczególnie rozpowszechnił się w Europie Wschodniej, a za prekursora tych badań uważa się J.S. Stiepanowa [1997]. Według tego badacza treść konceptu nie ogranicza się do zespołu cech dystynktywnych (składników semantycznych), lecz zawiera także informację o formie wewnętrznej i historii znaku, skojarzenia semantyczne, presupozycje, implikacje (w tym wartościujące) i in. Najważniejsze aspekty konceptu można ująć na trzech poziomach:

forma wewnętrzna (znaczenie motywacyjne)

$\frac{\text { znaczenie leksykalne - słownikowe, „systemowe”, ogólne }}{\text { znaczenie leksykalne - specjalistyczne, „kognitywne”, szczególne }}$

Forma wewnętrzna znaku stanowi podstawowy element jego interpretacji semantycznej, który jednak nie zawsze odpowiada pojęciu leksykalnemu. Zakodowana $\mathrm{w}$ formie i strukturze znaku interpretacja desygnatu

${ }^{2}$ K. Kleszczowa w czasie jednej z konferencyjnych dyskusji zwróciła uwage na to, że pojęcie „normalnych” użytkowników języka jest nie do zaakceptowania, ponieważ ludzie często posługują się kilkoma odmianami języka narodowego, uczestniczą w dyskursach różnego typu, zarówno potocznych, jak i oficjalnych oraz eksperckich. Dlatego bardziej sensowne, zdaniem K. Kleszczowej, jest mówienie o „normalnych”, tzn. najmniej wyspecjalizowanych sytuacjach użycia języka.

3 Zwraca na to uwage także A. Awdiejew [1999, 39], wskazujac, że słownikowa definicja rzeczownika ręka 'chwytna część kończyny górnej u człowieka i u naczelnych, składająca się $z$ nadgarstka, śódręcza i palców' nie jest zgodna $z$ doświadczeniem potocznym, w świetle którego jest to 'narzędzie działania'.

4 S.G. Workaczew [2010, 6] pisze, że całokształt konceptów jest tożsamy $z$ narodowym obrazem świata (ros. национальная картина мира). 
może odzwierciedlać pojęcia, które nie występują we współczesnym kulturowym obrazie świata ani w systemie semantycznym współczesnego języka [więcej o tym zob. Hansen 2006, 172]. Na przykład forma wewnętrzna rzeczownika schody (< schodzić) eksponuje określony (tylko jeden) kierunek ruchu: $z$ góry w dół, podczas gdy znaczenie leksykalne tego wyrazu ma szerszy charakter: 'konstrukcja, będąca zwykle częścią budowli, składająca się $z$ szeregu stopni, często $z$ poręczami, umożliwiająca przechodzenie $z$ jednego poziomu na inny' [zob. Bańko 2013; Kiklewicz 2017b, 111].

Podobnie jak forma wewnętrzna nie obejmuje wszystkich elementów pojęcia leksykalnego, tak i pojęcie leksykalne nie obejmuje wszystkich elementów ludzkiej (w tym tzw. eksperckiej) wiedzy o desygnacie znaku. Był o tym przekonany wspomniany wcześniej A.A. Potiebnia:

Rozumienie mowy wymaga obecności (...) wielu relacji występujacych w mowie zjawisk do innych zjawisk, które w potoku mowy pozostaja poza granicami świadomości [1976, 245].

Taki charakter pojęcia leksykalnego jest uwarunkowany faktem, że komunikacja na poziomie ogólnym (tzn. $z$ udziałem podmiotów, które łączy jedynie przynależność do jednej wspólnoty narodowej) wymaga zastosowania „uśrednionej” kompetencji semantycznej - ani zbytecznego uszczegółowienia, ani nadmiernej schematyzacji. O tym, że każda kultura powoduje niwelowanie indywidualnych różnic, pisał N.S. Trubiecki [1990, 154].

O ile lingwistyka kulturowa (lingwokulturologia) przyjmuje za podstawę opozycję „znaczenie (leksykalne, słownikowe) vs koncept”, o tyle teza lingwistyki kognitywnej, że „znaczenie jest równoznaczne $z$ konceptualizacja”, odwrotnie, rzutuje na spójny, kontynuacyjny charakter semantycznego systemu języka, w którym obowiązują ogólne zasady. To drugie stanowisko wydaje się bardziej adekwatne do obiektywnego stanu rzeczy, choć pojęcie konceptualizacji wymaga doprecyzowania (z lingwistycznego punktu widzenia).

\section{ZNACZENIE LEKSYKALNE JAKO KATEGORIA KOGNITYWNA}

Znaczenie leksykalne (słownikowe) w języku ogólnym nie odzwierciedla całej wiedzy członków wspólnoty językowej o danym desygnacie, ale $z$ drugiej strony - nie można też twierdzić, że znaczenie leksykalne jest niekognitywne: słownictwo ogólne reprezentuje minimalny zasób wiedzy, niezbędny do celów komunikacji na poziomie wspólnoty. Każda społeczność kulturowa wytwarza takie minimum jako pewien kompromis między integracja społeczną za pośrednictwem informacji a ciagle narastającą kumulacją i jednocześnie dyferencjacją ludzkiej wiedzy. 
S. Hall [1980, 59] pisze, że jednostki słownictwa ogólnego odzwierciedlaja charakterystyczny dla danej wspólnoty językowej sposób postrzegania świata. To twierdzenie wymaga pewnego doprecyzowania: postrzeganie świata zależy od określonego poziomu (a także kierunku) ludzkiej (komunikacyjnej lub niekomunikacyjnej) działalności. Językowy obraz świata, który możemy zrekonstruować na podstawie słownictwa ogólnego, istotnie różni się od obrazu zakodowanego w terminologiach oraz w tekstach branżowych. Dlatego spotykane w literaturze etnolingwistycznej przeciwstawienie językowego i naukowego obrazu świata jest bezpodstawne, podobnie jak bezpodstawne jest twierdzenie, że „język ma własna logikę" [Norman 1996]. Pod względem reprezentacji rzeczywistości język jest ambiwalentny, jako że znajdują w nim wyraz różne obrazy świata, nie tylko potoczny, lecz także naukowy, medialny, artystyczny, religijny, administracyjny, marketingowy itd.

Znaczenia leksykalne w języku ogólnym mają charakter bezosobowy, podczas gdy w sytuacjach użytkowania zachodzi ich specyfikacja - w zależności od tego, kto mówi, do kogo, w obecności kogo, w jakim kontekście, w ramach jakiej interakcji międzyludzkiej itd. Istnieja wyspecyfikowane odmiany wiedzy, np. stosowanej przez grupy zawodowe lub środowiskowe, rozbudowane o elementy poznawcze, które zostały wytworzone na potrzeby skutecznego orientowania się w określonej dziedzinie życia. W tym wypadku opis semantyczny wymaga stosownej atrybucji kulturowej, a często też subkulturowej.

W pewnym uproszczeniu wymienione wyżej trzy poziomy specyfikacji semantycznej można przedstawić następująco:

- forma wewnętrzna - użytkownicy języka mają dostęp do znaczen nia składników;

- znaczenie leksykalne (ogólne) - użytkownicy języka maja dostęp do $z$ naczenia-znaku (zakodowanego w nim pojeccia) na tyle, na ile jest to wymagane, żeby desygnat znaku był możliwy do odróżnienia od innych desygnatów;

- znaczenie konceptualne (szczególne, eksperckie) - użytkownicy języka maja dostęp do znaczenia desygnatu, tzn. opartego na doświadczeniu i wiedzy specjalistycznej.

Na każdym $z$ tych poziomów są wykorzystywane różne zasoby kompetencji poznawczej i odpowiednie kody symboliczne. Przetwarzanie formy wewnętrznej wymaga znajomości kodu ograniczonego, czyli zespołu składników pierwotnych - tematów niepochodnych oraz formantów, które występują w niedużej liczbie. Na przykład jeśli ktoś po raz pierwszy słyszy rzeczownik wałęsizm, ale wie, że Wałęsa to polski działacz polityczny oraz że -izm to formant oznaczający zjawisko, tendencję, doktrynę, teorię itd., będzie w stanie wygenerować (co najmniej ogólne, przybliżone) znaczenie derywatu. Nieprzypadkowo kodem ograniczonym najczęściej posługują się dzieci, wykorzystując swoją nierozbudowaną jeszcze kompetencję semantyczną. 
Znaczenia leksykalne sa realizowane za pomoca kodu podstawowego, który jest tożsamy $z$ pojęciem słownictwa ogólnego. Ten kod, w porównaniu $z$ poprzednim, jest o wiele bardziej rozbudowany: statystyczny użytkownik języka zna ponad 40 tys. wyrazów [Brysbaert, Stevens, Mandera $i$ in. 2016], choć jeszcze większa specyfikacja semantyczna zachodzi w dyskursach środowiskowych (branżowych, fachowych itd.), których uczestnicy posługują się kodem rozszerzonym: słownictwo ogólne zostaje wzbogacone o systemy terminologiczne, a poza tym wzrostowi zasobu leksykalnego towarzyszy coraz większa specyfikacja pojęć. Na przykład w dyskusji lingwistycznej nie można zadowolić się definicją zdania jako „myśli wyrażonej słowami”, choć właśnie takie znaczenie tego wyrazu (zgodnie $z$ definicją słownikowa) występuje w języku ogólnym.

\section{ATRYBUCJA ZNACZENIA}

Ogólna teza lingwistyki kulturowej o podmiotowym, idioetnicznym charakterze konceptualizacji nie budzi wątpliwości. J. Bartmiński słusznie pisze, że kulturowe konotacje znaków językowych sa subiektywnie determinowane i odzwierciedlają interpretację rzeczywistości w ramach określonych „społecznych modeli poznawczych” [1998, 64]. Uznanie subiektywnego charakteru mentalnej kategoryzacji doświadczeń nie rozwiąuje jednakże zasadniczego problemu lingwistyki funkcjonalnej, którym jest wyjaśnienie mechanizmów działalności językowej. Problem m.in. tkwi w tym, że funkcjonalna atrybucja semantyki językowej wymaga - w określeniu D. Hymesa [1996, 33 i n.] - k o n te k s tuali z a cji. Teza kognitywizmu, iż „semantyka jest encyklopedyczna”, budzi wątpliwości dlatego, że człowiek nie korzysta $z$ tego samego („encyklopedycznego") zasobu wiedzy w różnych warunkach swojej działalności odwrotnie, działając zgodnie $z$ zasadą adaptacyjności, dostosowuje wiedzę do swoich potrzeb, w dużym stopniu uwarunkowanych tzw. kontekstem sytuacji. Czytając książkę, nie muszę pamiętać, że papier wynaleźli Chińczycy, podobnie jak kupując gazetę, nie uświadamiam sobie, że druk wynaleziono w Niemczech w XV wieku. Kategorie semantyczne (pojęciowe, mentalne) sa rozbudowane o tyle, o ile tego wymaga kontekst sytuacyjny, a także dyskurs. W zwiazku z tym M.L. Makarow pisze:

Modele poznawcze nie moga być czymś, co istnieje osobno i poza dyskursem. (...) Dyskurs to nie tylko „substancja” do zrealizowania, lecz także źródło modeli poznawczych [2003, 160].

Nawiązanie do dyskursu wymaga zasadniczej reinterpretacji znaczenia jako arbitralnej kategorii semantycznej na rzecz ujęcia relatywistycznego, tzn. $z$ uwzględnieniem atrybucji kulturowo- pragmatycznej znaków. Znaczenie nie jest kategorią stała, lecz pochodna wobec „społecznych modeli poznawczych”, produktem interakcji 
między podmiotem a kontekstem sytuacji. Dlatego np. to samo wyrażenie ferszlusroztrajbować w znanej humoresce Juliana Tuwima ma inne znaczenie w mowie zawodowego ślusarza, inne w mowie gospodarza „zwykłego” użytkownika języka.

Jak ważny jest czynnik pragmatyczny w opisie semantycznym, pokazuje przeprowadzona przez J. Bartmińskiego [1999, 113] analiza „systemowej" interpretacji rzeczownika gwiazda: odwołanie się do informacji stricte naukowej (gwiazdy sa złożone $z$ gazów, mają budowę podobną do Słońca itd.) nie odpowiada potrzebom komunikacji codziennej. Zresztą tego wymogu nie spełnia też zaproponowana przez J. Bartmińskiego alternatywna definicja „kognitywna”: informacja o tym, że gwiazdy towarzysza człowiekowi od urodzenia do zgonu, że swoim układem i zachowaniem wróżą ludziom ich losy itd., jest zbyteczna $z$ punktu widzenia komunikacji potocznej, choć oczywiście może być istotna w dyskursach artystycznych, mitologicznych, parapsychologicznych i in. Podobnie nierozstrzygalny status maja koncepty $\mathrm{w}$ teorii J.S. Stiepanowa: $z$ jednej strony - sa to „konstanty kultury”, ale $z$ drugiej strony - sa generalizowane na podstawie okazjonalnych i często subiektywnych doświadczeń. ${ }^{5}$

L.M. Wasiliew [2006, 32] pisał, że w mowie jednostki leksykalne wyrażają komunikacyjnie relewantne elementy ludzkiej wiedzy o świecie, które nie sa obecne w treści tych jednostek w systemie języka. To słuszna konstatacja, jednak w rzeczywistości na każdym poziomie specyfikacji semantycznej, zarówno w języku ogólnym, jak i w językach (a także tekstach) specjalistycznych (w tym idiolektach), znaczenie jest komunikacyjnie relewantne, $z$ tym że każdy kontekst komunikacyjny wymaga innej specyfikacji semantycznej. Inny zasób wiedzy wykorzystujemy w rozmowie $z$ dzieckiem, inny - w rozmowie $z$ obcym dorosłym, inny - w rozmowie $z$ kolega $z$ pracy, jeszcze inny - w rozmowie $z$ członkami rodziny itd.

\section{TREŚĆ A ZAKRES STOSOWANIA KONCEPTU}

W zależności od podmiotu oraz kontekstu sytuacji można, zgodnie ze stanowiskiem P. Bourdieu [1974, 46], rozróżniać koncepty: uniwersalne, ogólnonarodowe, regionalne, lokalne, grupowe, środowiskowe i in. Każ-

5 Dlatego nie można jednoznacznie zinterpretować opozycji: realizm vs antyrealizm, o której pisze Z. Muszyński [1996, 34]. Według tego badacza w wypadku realizmu „prawda jest oparta na obiektywnych relacjach semantycznych”, a w wypadku antyrealizmu zależy od subiektywnych założeń badaczy. Trudno jest rozstrzygnąć, które ujęcie: neopozytywistyczne (nomotetyczne, algorytmiczne) czy fenomenologiczne (idiograficzne, kulturalistyczne) jest bardziej obiektywne: strukturalizm nadmiernie eksponował systemowe, immanentne programowanie działalności językowej, podczas gdy współczesne wersje językoznawstwa „otwartego" wyolbrzymiaja rolę czynników zewnętrznych: kognitywnych, pragmatycznych, kulturowych. 
demu z nich przysługuje inny stopień specyfikacji semantycznej. Istnieje ogólna zasada, określająca relacje między treścią konceptu a zakresem jego stosowania pragmatycznego: im szersza jest treść konceptu, tym węższy zakres jego zastosowania (co przypomina zależność, znaną z logiki formalnej). Wobec tego można wyodrębnić cztery typy konceptów:

- informacja semantyczna zminimalizowana lub zerowa;

- niska specyfikacja semantyczna;

- wysoka specyfikacja semantyczna;

- ekspansja semantyczna.

Można je przedstawić graficznie: zacieniowane obszary oznaczaja zakres stosowania, jasne obszary (w granicach koła) - treść konceptu.

$\mathbf{A B}$
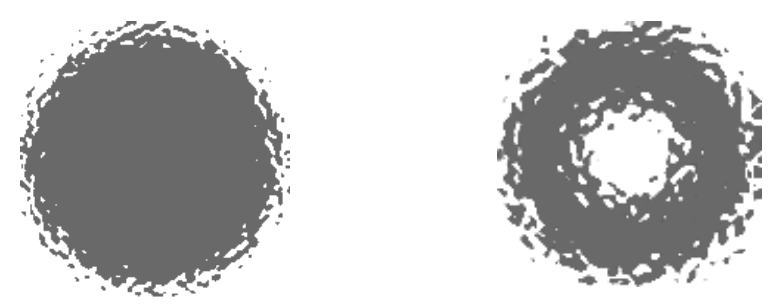

CD
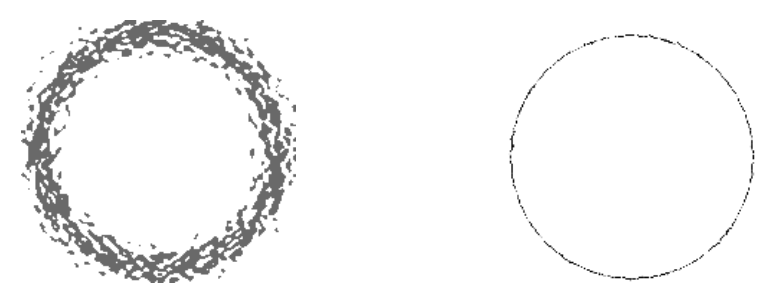

Do typu A należą maksymalnie uniwersalne koncepty o zminimalizowanej treści, charakterystyczne dla rodzaju ludzkiego, np. takie, które A. Wierzbicka określiła jako „semanticprimes”. Moga to być archetypowe „koncepty bez nazw” (termin J.S. Stiepanowa) albo takie, które sa realizowane w formach niewerbalnych - ikonicznych lub symptomatycznych.

Koncepty typu B funkcjonuja na poziomie wspólnot narodowych bądź regionalnych: zawarta w koncepcie informacja semantyczna jest dostępna dla wszystkich członków wspólnoty, poza obszarami działalności specjalistycznej (czyli tzw. wiedzy eksperckiej). Nazwy tego rodzaju konceptów składają się na słownictwo ogólne.

Trzeci typ konceptów realizuje się w relacjach subkulturowych, środowiskowych, specjalistycznych. Tego typu koncepty sa o wiele bardziej rozbudowane semantycznie - właśnie tego wymaga charakter ludzkiej działalności, zawężony do określonej sfery. 
Można wątpić, czy typ D w ogóle jest możliwy: czy mogą istnieć koncepty bez sfery zastosowania? Owszem, jest to możliwe w wypadku celowej kompilacji informacji semantycznej, związanej $z$ jakimkolwiek obiektem rzeczywistości. Właśnie tak wyglądają współczesne opisy konceptów w wielu publikacjach w zakresie lingwokulturologii (szczególnie rozpowszechnionych w Europie Wschodniej), czego przykładem może być wspomniana monografia J.S. Stiepanowa [1997; zob. także: Karasik 2009; Pimienowa 2010; Wołkow 2017 i in.]. Autorzy tych publikacji gromadza dane, pozyskiwane $z$ rozmaitych (w przestrzeni i czasie) źródel, tworząc koncepty jako sztuczne kompendia wiedzy. Całość tej informacji, teoretycznie rzecz biorac, może zostać zmagazynowana w zasobach Internetu, ale nie jest prawdopodobne, żeby stanowiła ona element jakiejkolwiek realnej (naturalnej) kompetencji poznawczej.

\section{ZAKOŃCZENIE}

Powyższe rozważania miały przyczynić się do uzasadnienia tezy o tym, że mentalna kategoryzacja doświadczeń, jak również specyfikacja semantyczna jednostek językowych, jest uwarunkowana czynnikiem kulturowo-pragmatycznym, tzn. kontekstem sytuacji, w których przychodzi nam posługiwać się językiem. Dysjunkcyjne odseparowanie od siebie interpretacji „systemowej” i „kognitywnej” znaczenia nie wydaje się jednak uzasadnione ani zgodne $z$ danymi empirycznymi. W działalności językowej obowiąuje zas ada relatywizmu: interpretacja „kognitywna”, jak również interpretacja „systemowa”, to dwie odmienne opcje realizacji informacji semantycznej w różnych warunkach działalności językowej. Rozmaite obszary, sfery, sytuacje i sceny ludzkiej działalności różnią się m.in. pod względem ogólności / szczególności, czyli zasobności kultywowanych modeli poznawczych: inny zakres wiedzy (kompetencji poznawczej) przysługuje komunikacji masowej, inny - fachowej komunikacji w przedsiębiorstwie, jeszcze inny - prywatnej komunikacji w rodzinie itd. Za sprawą dywersyfikacji obszarów ludzkiej działalności zachodzi zróżnicowanie specyfikacji pojęć leksykalnych, które składaja się na językowy obraz świata. Jego zawartość zmienia się w zależności od tego, czy chodzi o komunikację na poziomie całej wspólnoty językowej (przy zastosowaniu słownictwa ogólnego), czy na poziomie subkulturowym (przy zastosowaniu systemów terminologicznych), czy na poziomie jednostek (przy zastosowaniu idiolektów). Podobnie jak istnieje formalna dyferencjacja systemu języka (co stanowi przedmiot stylistyki i socjolingwistyki), istnieje też jego zróżnicowanie semantyczne, m.in. ze względu na większą lub mniejszą specyfikację znaczeń, na co wcześniej zwrócił uwage J.M. Łotman [1983, 98].

Badacze, należący do nurtu lingwokulturologii, sa skłonni wyolbrzymiać różnice między znaczeniem leksykalnym (słownikowym) a koncep- 
tem, uważając, że tylko koncept jest realna formą przetwarzania (dającej się zwerbalizować) informacji w umyśle. W rzeczywistości opozycja „znaczenie vs koncept" ma charakter gradualny: różnica między pierwszym a drugim polega na stopniu specyfikacji semantycznej, czyli zasobach informacji dostosowanej do potrzeb działalności na różnych poziomach systemu społecznego, w obrębie różnych, według już przytoczonego określenia J. Bartmińskiego, „społecznych modeli poznawczych”. Wskazówki co do takiego rozwiazania problemu dywersyfikacji systemu semantycznego można znaleźć w kognitywnej teorii poziomów kategoryzacji doświadczeń. Jak pisze E. Tabakowska [1995, 46], kategorie pojęciowe różnego stopnia ogólności sa pragmatycznie nacechowane: kategorie bazowe funkcjonuja w dyskursach potocznych, podczas gdy kategorie wyższego i niższego rzędu - w dyskursach specjalistycznych. Wobec tego w zjawiskach kategoryzacji i nominacji leksykalnej można upatrywać pewną symptomatyczność, czyli relację „poprzednik (kontekst sytuacji) vs następnik (pojęcie)”. Dla językoznawców oznacza wymóg przeprowadzenia badań semantycznych w odniesieniu do jednostek wstępnie zinterpretowanych pod względem pragmatyczno-kulturowym.

\section{Bibliografia}

A. Awdiejew, 1999, Standardy semantyczne $w$ gramatyce komunikacyjnej (teoria i zastosowanie) [w:] A. Awdiejew (red.), Gramatyka komunikacyjna, Warszawa-Kraków, s. 33-68.

A. Awdiejew, 2004, Gramatyka interakcji werbalnej, Kraków.

M. Bańko, 2013, Schody i wychody, „Wyspa” 3, s. 29-30.

J. Bartmiński, 1998, Podstawy lingwistycznych badan nad stereotypem - na przykładzie stereotypu matki, „Język a kultura” XII, s. 63-83.

J. Bartmiński, 1999, Punkt widzenia, perspektywa, jezzykowy obraz świata [w:] J. Bartmiński (red.), Językowy obraz świata, Lublin, s. 103-120.

P. Bourdieu, 1974, Zur Soziologie der symbolischen Formen, Frankfurt am Main.

M. Brysbaert, M. Stevens, P. Mandera i in., 2016, How Many Words Do We Know? Practical Estimates of Vocabulary Size Dependent on Word Definition, the Degree of Language Input and the Participant's Age, „Frontiers in Psychology" 7, s. 1-11.

W.Z. Demiankow [В.3. Демьянков], 1994, Когнитивная лингвистика как разновидность интерпретирующего подхода, „Вопросы языкознания” 4, s. 17-33.

R. Gibbs, T. Matlock, 2001, Psycholinguistic Perspectives on Polysemy [w:] H. Cuyckens, B. Zawada (red.), Cognitive Linguistics. Selected Papers from the Fifth International Cognitive Linguistics Conference, Amsterdam-Philadelphia, s. 213-240.

S. Hall, 1980, Culture studies: two paradigms, „Media, Culture and Society” 2, s. $57-72$. 
В. Hansen, 2006, Экономные как немиы. Наииональные стереотипы и их отражение в коннотаииях этнонимов в русском и других языках, „Аста Neophilologica" VIII, s. 163-173.

D. Hymes, 1996, Ethnography, Linguistics, Narrative Inequality. Toward an Understanding of Voice, London.

W.I. Karasik [В.И. Карасик], 2009, Языковые ключи, Москва.

H. Kardela, 1999, Ogdena i Richardsa trójkąt uzupełniony, czyli co bada gramatyka kognitywna [w:] J. Bartmiński (red.), Językowy obraz świata, Lublin, s. $15-38$.

A. Kiklewicz, 2017a, Nieokreśloność a semantyczna specyfikacja grupy imiennej [w:] M. Danielewiczowa, K. Doboszyńska-Markiewicz, A. Wójcicka (red.), Nieokreśloność i granice, Warszawa, s. 119-138.

A. Kiklewicz, 2017b, Znaczenie a prawda. Fantomy semantyczne, Olsztyn.

J.M. Łotman [Ю.М. Аотман], 1983, K построению теории взаимодействия культур (семиотический аспект), „Ученые записки ТГУ” 646, s. 93-112.

M.L. Makarow [M.^. Макаров], 2003, Основы теории дискурса, Москва.

Z. Muszyński, 1996, Światy za słowami. Ich natura i porzadek [w:] R. Grzegorczykowa, A. Pajdzińska (red.), Językowa kategoryzacja świata, Lublin, s. $27-45$.

B.J. Norman [Б.Ю. Норман], 1996, Скорости оставляют позади катера? О логике естественного языка, „Русская речь” 6, s. 24-28.

M.W. Pimienowa [M.В. Пименова], 2010, О культурных стереотипах (представления о мудреие в русской и английской лингвокультурах) [w:] A. Kiklewicz, A. Kamałowa (red.), Кониепты культуры в языке и тексте: теория и анализ, Olsztyn, s. 101-115.

A.A. Potiebnia [А.А. Потебня], 1976, Эстетика и поэтика, Москва.

A.A. Potiebnia [А.А. Потебня], 1993, Мысль и язык, Киев.

J.S. Stiepanow [Ю.С. Степанов], 1997, Константы. Словарь русской культуры. Опыт исследования, Москва.

E. Tabakowska, 1995, Gramatyka i obrazowanie. Wprowadzenie do językoznawstwa kognitywnego, Kraków.

E. Tabakowska, 2001, Językoznawstwo kognitywne a poetyka przekładu, Kraków.

N.S. Trubiecki [Н.С. Трубецкой], 1990, Вавилонская башня и смешение языков, „ИАН ОАЯ” 2/49, s. 152-160.

S. Ullmann, 1967, Grundzüge der Semantik. Die Bedeutung in sprachwissenschaftlicher Sicht, Berlin-New York.

L.M. Wasiliew [^.М. Васицьев], 2006, Теоретические проблемы обшей лингвистики, славистики, русистики, Уфа.

W.W. Wołkow [В.В. Волков], 2017, Аингвокультурный кониепт "война": семантическое ядро, аспекты герменевтического исследования, „Вестник ТвГУ, серия "Филология” 1, s. 103-113.

S.G. Workaczew [С.Г. Воркачев], 2010, "Кудаж нам плыть?" Аингвокультурная кониептология: современное состояние, проблемы, вектор развития, „Язык, коммуникация и социальная среда” VIII, s. 5-27. 


\section{From meaning to concept: \\ pragmatic and cultural aspects of semantic specification}

\section{Summary}

The author discusses theoretical issues of functional semantics, especially such directions of the contemporary anthropological linguistics as ethnosemantics and cognitive semantics. The diversification of the content of a lexical meaning under the influence of external, mainly pragmatic and cultural, factors is the primary object of interest here. Therefore, the author considers the degree of semantic specification of lexical units at various levels of interpersonal communication: both general and subcultural. As assumed by the contemporary cultural linguistics, a concept is considered to be a category of representation of knowledge encoded in language signs. The author gives arguments in favour of the view that the opposition of the (lexical, general) meaning and concept is gradual and concerns the scope of semantic information encoded in the sign in accordance with adaptive requirements.

Keywords: lexis - semantics - structuralism - cognitivism - pragmalinguistics

Adj. Monika Czarnecka 